\title{
PUBLIC TRANSPORTATION DURING THE COVID-19 PANDEMIC IN THE CITY OF ZAGREB
}

\author{
Dora Naletina*
}

\begin{abstract}
The pandemic caused by the coronavirus has shaken the entire world. It has, like no pandemic before, deeply impacted the mobility of the population on a global scale. Almost all the member states, including the Republic of Croatia, had public transport services put on hold and the mobility of the people who travel abroad was possible only under specific conditions. Public transport represents an extremely important segment of each society, and its role has been gaining importance in recent years since sustainable transport is in everybody's best interest. Even in these difficult times, decision-makers need to be aware of the fact that an efficient system of public transport is of great importance, and they need to find a solution to the problem that arose because many have lost trust in the public transport system for fear of their health. The findings of the studies so far have confirmed that there have been changes happening in the transport behavior and that it is crucial to revise the existing strategies of public transport development to regain trust and to ensure the conditions for sustainable transport. In Croatia's capital, a drop of the number of passengers in all segments of urban transit has been recorded, but the encouraging fact is that it is smaller than in other EU member states. To be able to operate at levels from before the pandemic, the authorities in the City of Zagreb will have to continue with the precautionary measures for minimizing the risk of transmission of the virus and with informing the public on a high level of safety. Moreover, the crucial action would have to be encouraging the tourists to return because they represent an extremely important factor in using the funicular.
\end{abstract}

KEYWORDS: public transport, COVID-19 pandemic, transport behavior, City of Zagreb

\footnotetext{
Dora Naletina, Faculty of Economics and Business, University of Zagreb, Zagreb, Croatia; dora.naletina@efzg.hr.
} 


\section{INTRODUCTION}

The pandemic caused by the coronavirus has, like an earthquake, shaking the entire world and is still affecting the population globally. ${ }^{1}$ It has affected all the segments of the society, the transportation sector included. While it has been necessary to ensure the same, and an even higher level of efficiency regarding the freight transport, first and foremost because of the transportation of medical supplies ${ }^{2}$, passenger transportation, especially public transport, has experienced limitations and even complete bans at certain points. Passenger transport has been affected by the fact that many had to work from home due to the lockdowns. Some cities have recorded a drop of $80 \%$ in public passenger transport ${ }^{3}$. It is indisputable that there is a widely accepted opinion on how public transportation represents a high risk regarding the spread of the coronavirus since it operates with enclosed vehicles (tram, bus, and train).

Public transport in urban areas is vital for the functioning of the city and its inhabitants and the pandemic has supported this statement even more. City offices have to ensure that events such as this pandemic do not impede public transit. ${ }^{4}$ Most global capital cities have been meeting transport demand through high-quality systems of public transport. ${ }^{5}$ As the answer to the pandemic caused by the coronavirus and with the aim of protecting the general population, almost all countries have adopted certain regulations to minimize the risk of virus transmission. ${ }^{6}$ To stop the virus from spreading, it has been of great importance to reduce social interaction in everyday life and this has

\footnotetext{
1 Przybylowski, A., Stelmak, S., Suchanek, M.: Mobility behaviour in view of the impact of the COVID-19 pandemic-public transport users in Gdansk case study, Sustainability, 13(1)2021, [https://doi.org/10.3390/su13010364], p. 364. [https://doi.org/10.3390/su13010364], p. 364.

2 [https://ec.europa.eu/info/live-work-travel-eu/coronavirus-response/transportationduring-pandemic_en], accessed on 26/08/2021.

3 Bernhardt, J.: Decline in ridership, adapted timetables and disinfection-robots - The impact of Corona/Covid-10 on public transport, Urban Transport Magzine, 25.03.2020. [https:// www.urban-transport-magazine.com/en/decline-in-ridership-adapted-timetables-and-disinfection-robots-the-impact-of-corona-covid-10-on-public-transport/], accessed on 05/09/2021.

4 The International Association of Public Transport (UITP): Public transport is COVID safe. Brussels: UITP, October 2020. [https://cms.uitp.org/wp/wp-content/uploads/2020/10/PolicyBrief-PTisCOVID-Safe.pdf], accessed on 05/09/2021.
}

5 Schmöcker, J. D., Bell, M. G., Lam, W. H. (2010): Importance of public transport, Journal of Advanced Transportation, 38(1)(2010), [https://doi.org/10.1002/atr.5670380102], pp. 1-14.

6 Zhen, J., Chan, C., Schoonees, A., Apatu, E., Thabane, L., Young, T.: Transmission of respiratory viruses when using public ground transport: A rapid review to inform public health recommendations during the COVID-19 pandemic, South African Medical Journal, 110(June 2020), [https://doi.org/ 10.7196/SAMJ.2020.v110i6.14751], pp. 478-483. 
affected both private and public transportation. ${ }^{7}$ The challenge of reducing this risk has not skipped Croatia either and the authorities have been trying to limit the number of passengers in urban public transport to help prevent the transmission of the coronavirus. We should try to make the most of this unexpected crisis because it has created the opportunity to transfer the focus from the segments such as new and modern technological interventions, methodology for managing the products and services, and sustainable mobility to other aspects such as individual and collective responsibility regarding public health during the crisis. ${ }^{8}$

The topic of this paper is the pandemic and the measures taken by the decision-makers and how they have affected the public transport sector. Principally, based on the overview of the existing research, the goal was to establish whether the pandemic has prompted the changes in the behavior in transport. More precisely, whether the passengers' preferences towards the use of public transport services have changed. Together with the analysis of the existing research, the statistical data for the public urban transport for the capital city of the Republic of Croatia - Zagreb will also be analyzed and presented. The paper is conceptualized in four sections. The introductory section explains the research problem, followed by the overview of the existing research, with the focus on urban public transport during the pandemic, with special attention given to the measures introduced for preventing the coronavirus from spreading in public transport. The third section focuses on public transportation in the Republic of Croatia during the pandemic, with special emphasis on the analysis of the statistical data for the country's capital (Zagreb). The fourth section presents the concluding remarks.

\section{PUBLIC TRANSPORT IN THE PANDEMIC TIMES}

This section of the paper provides an overview of the selected studies that focus on the impact of the coronavirus pandemic on public transport and look into its influence on the consumers' behavior. The second subsection considers the measures implemented with the aim of reducing the risk of virus transmission in public transport.

\footnotetext{
7 Rasca, S., Markvica, K., Ivanschitz, B. P.: Impacts of COVID-19 and pandemic control measures on public transport ridership in European urban areas-The cases of Vienna, Innsbruck, Oslo, and Agder, Transportation Research Interdisciplinary Perspectives, Vol. 10(June)2021, [https://doi.org/10.1016/j.trip.2021.100376], p. 100376.

8 Budd, L., Ison, S.: Responsible Transport: A post-COVID agenda for transport policy and practice, Transportation Research Interdisciplinary Perspectives, 6(July 2021), [https:// doi.org/10.1016/j.trip.2020.100151], p. 100151.
} 


\subsection{LITERATURE OVERVIEW}

In times of great crisis, such as we are experiencing today, transport services are certainly of vital importance. They are also susceptible to rapid changes. ${ }^{9}$ Safety measures that have been implemented during the pandemic have made public transport probably the safest place on Earth. If these measures were used in other high-risk segments of our everyday lives, the spreading of the disease would be considerably slower. For example, the research conducted in France shows that only $1.2 \%$ of the cases in the cluster relate to the transportation sector (whether it is air, maritime, or railway transport). ${ }^{10}$ Less contact among the passengers in public transport considerably reduces the possibility of virus transmission. Therefore, some countries have decided to introduce strict measures. In Japan, people were forbidden to converse on the subway, despite the fact that it is one of the busiest subways in the world. ${ }^{11}$ More and more studies are proving that the results of the measures against the COVID-19 implemented in public transport are considerably more effective than in other sectors. ${ }^{12}$

The coronavirus pandemic has influenced all segments of our lives, especially the mobility of the entire global population. To be able to establish whether there has been a change in consumers' behavior i.e., whether the preferences for specific forms of transport have remained the same, Eisenmann et al. (March 2021) conducted research on the sample of 1000 respondents in Germany. The results for the spring of 2020 show that more people used only one mode of transport compared to the period before the pandemic. Men used public transport less often (a drop from $22 \%$ to 10\%). A drop was recorded for women as well, but on a smaller scale (from 24\% to 15\%). During the period of the complete lockdown, individual transport gained on importance (private cars in particular). ${ }^{13}$ While senior citizens are less likely to use the pub-

9 Borkowski, P., Jażdżewska-Gutta, M., Szmelter-Jarosz, A.: Lockdowned: Everyday mobility changes in response to COVID-19, Journal of Transport Geography, 90(January 2021), [https://doi.org/10.1016/j.jtrangeo.2020.102906], p. 102906.

10 Culbertson, A., Aguilar-Garcia, C.: Coronavirus: Why public transport could be safer than we thought, Sky News, 07.10.2021. [https://news.sky.com/story/coronavirus-why-publictransport-could-be-safer-than-we-thought-12091657], accessed on 11/10/2021.

11 Culbertson, A., Aguilar-Garcia, C.: Coronavirus: Why public transport could be safer than we thought, Sky News, 07.10.2021. [https://news.sky.com/story/coronavirus-why-publictransport-could-be-safer-than-we-thought-12091657], accessed on 11/10/2021.

12 The International Association of Public Transport (UITP): Public transport is COVID safe. Brussels: UITP, October 2020. [https://cms.uitp.org/wp/wp-content/uploads/2020/10/ Policy-Brief-PTisCOVID-Safe.pdf], accessed on 05/09/2021.

13 Eisenmann, C., Nobis, C., Kolarova, V., Lenz, B., Winkler, C.: Transport mode use during the COVID-19 lockdown period in Germany: The car became more important, pub- 
lic transport services during the pandemic, they are more likely to use these services if there were precautionary measures to be followed. ${ }^{14}$ Przybylowski et al. (December 2020) carried out primary research in Gdansk (Poland) to establish whether the pandemic has had an impact on the mobility of the consumers i.e., more importantly, how it has reflected on consumers' preferences regarding the use of the public transport services. The key hypothesis of the research was that the pandemic makes passengers avoid public transport and the results confirm this hypothesis. $90 \%$ of the respondents confirm they have reduced or completely stopped using the public transport services in the times of the pandemic. The results have also revealed one alarming fact: one-quarter of the respondents stated they would not use the public transport services even when the pandemic is over because they think it will never be safe again. ${ }^{15}$ This definitely does not comply with the goals the European Commission has set, and which mandate the use of different measures, so the citizens are encouraged to use public transport, all with the aim to reduce pollution and achieve a higher level of sustainability in transport. It is worrying that there is still a stigma about public transport being high-risk in times of pandemics, which has also prompted the rise in the use of private cars as the mode of transport. It is a sad fact that many governments have diverted people from using public transport without consulting the experts. These decisions have often been influenced by the media and that is why many are encouraged to use other modes of transportation. People are feeling unsafe in public spaces, public transport included, which shows how their behavior has changed. ${ }^{16}$ The frameworks that have been drawn for public transport development ${ }^{17}$ and sustainable individual transport are influenced by the fact that more people have started using their

lic transport lost ground, Transport policy, 103(March 2021), [https://doi.org/10.1016/j.tranpol.2021.01.012], pp. 60-67.

14 Abdullah, M., Ali, N., Dias, C., Campisi, T., Javid, M. A.: Exploring the Traveler's Intentions to Use Public Transport during the COVID-19 Pandemic While Complying with Precautionary Measures, Applied Sciences, 11(8)2021, [https://doi.org/10.3390/app11083630], p. 3630.

15 European Commission: Clean transport, Urban transport, Public transport. [https://ec.europa.eu/transport/themes/urban/urban_mobility/urban_mobility_actions/public_transport_ en], accessed on 11/09/2021.

16 The International Association of Public Transport (UITP): Public transport is COVID safe. Brussels: UITP, October 2020. [https://cms.uitp.org/wp/wp-content/uploads/2020/10/ Policy-Brief-PTisCOVID-Safe.pdf], accessed on 05/09/2021.

17 Eisenmann, C., Nobis, C., Kolarova, V., Lenz, B., Winkler, C.: Transport mode use during the COVID-19 lockdown period in Germany: The car became more important, public transport lost ground, Transport policy, 103(March 2021), [https://doi.org/10.1016/j.tranpol. 2021.01.012], pp. 60-67. 
private vehicles. ${ }^{18}$ The research conducted by the European Investment Bank proves the hypothesis that people are concerned about their health and therefore afraid of using public transport during the coronavirus crisis. ${ }^{19}$

Since viruses spread through close contact, public transport has suffered a huge blow due to the coronavirus pandemic because people avoid enclosed and crowded places..$^{20}$ It is therefore understandable that people do not want to use any of the options provided by the public transport services (bus, train, subway, light rail, ride-hail) together with shared mobility options like bikes and scooters, and that their use has dropped by $86 \%$ in the Italian regions that have experienced terrible consequences of the coronavirus spread (Milan and Lombard). ${ }^{21}$ It seems that the effects of the pandemic on public transport depend not only on the measures implemented by the authorities and the number of people infected by COVID-19 but also on the size of the urban area and the time the outbreak happened. ${ }^{22}$ Borkowski et al. have based their research on the hypothesis that the coronavirus pandemic has undisputedly impacted the everyday mobility of the population, but this does not mean that public transport should be regarded as a route for transmitting the virus. The primary research that was conducted in Poland suggests that individual travel time was reduced by $66 \%$ across all age groups. However, different occupations mean different reductions in travel time. Those who did not work from home report the least reductions in commuting, but overall reductions go as far as $50 \%$ because of the reduced use of public transport for activities other than work (leisure activities, shopping). ${ }^{23}$

18 Przybylowski, A., Stelmak, S., Suchanek, M.: Mobility behaviour in view of the impact of the COVID-19 pandemic-public transport users in Gdansk case study, Sustainability, 13(1)2021, [https://doi.org/10.3390/su13010364], p. 364.

19 Abdullah, M., Ali, N., Dias, C., Campisi, T., Javid, M. A.: Exploring the Traveler's Intentions to Use Public Transport during the COVID-19 Pandemic While Complying with Precautionary Measures, Applied Sciences, 11(8)2021, [https://doi.org/10.3390/app11083630], p. 3630.

20 [https://www.eib.org/en/infographics/67-percent-eu-avoiding-public-transport-health-concerns], accessed on 18/09/2021.

${ }^{21}$ Krell, K., Hunkin, S.: Making Public Transport safe \& acceptable in times of cOVID-19. Interreg Europe. Policy Learning Platform, 07 July 2020. [https://www.interregeurope.eu/fileadmin/user_upload/plp_uploads/PLP_COVID-PublicTransport.pdf], accessed on 12/09/2021.

22 Rasca, S., Markvica, K., Ivanschitz, B. P.: Impacts of COVID-19 and pandemic control measures on public transport ridership in European urban areas-The cases of Vienna, Innsbruck, Oslo, and Agder, Transportation Research Interdisciplinary Perspectives, Vol. 10(June)2021, [https://doi.org/10.1016/j.trip.2021.100376], p. 100376.

23 Borkowski, P., Jażdżewska-Gutta, M., Szmelter-Jarosz, A.: Lockdowned: Everyday mobility changes in response to COVID-19, Journal of Transport Geography, 90(January 2021), [https://doi.org/10.1016/j.jtrangeo.2020.102906], p. 102906. 
Google and Apple mobility data have provided the information for the analysis of consumers' behavior in four Japanese metropolitan areas. They support the findings of many studies that the pandemic has affected the behavior of the consumers and that these behaviors vary according to different urban structural and climatic factors. ${ }^{24}$ The example of Sidney, Australia, shows how measures implemented due to the coronavirus pandemic cause the behavior to change. There have been fewer private vehicles on the roads, and many have taken up cycling as an alternative due to the temporary closure of the gyms. The primary research has confirmed the changes in the behavior regarding cycling during the pandemic. ${ }^{25}$ More people have opted for cycling than before and this behavior is directly connected to the COVID-19 pandemic. Our experience teaches us that people's behaviors change in times of crisis. This is also true of the public transport services, where consumers look at the options and choose the most suitable one. ${ }^{26}$

Public transport providers are having a hard time dealing with the consequences of the pandemic. The maintenance and upgrade of their services are costly, but they have to appeal to their users again. Some measures have been introduced to regain the trust of the passengers ${ }^{27}$ :

- Technology-based measures - for example, continuously updated information on the occupancy to help the passengers decide which route to take and which to avoid. However, this can divert them from using the public transport services at all.

- Additional personnel on the vehicles and at the stations who can provide accurate information, guide the passengers, and ensure compliance with the COVID-19 measures, protecting the health of the passengers.

- Vehicle cabins are cleaned and disinfected (in particular handrails and control knobs) several times a day.

24 Morita, H.; Nakamura, S.; Hayashi, Y.: Changes of Urban Activities and Behaviors Due to COVID-19 in Japan, SSRN Electron, May 2020. [https://papers.ssrn.com/sol3/papers.cfm?abstract_id=3594054], accessed on 14/09/2021.

25 Lock, O.: Cycling Behaviour Changes as a Result of COVID-19: A Survey of Users in Sydney, Australia, Findings, 2020.

26 Sung, J., Monschauer, Y.: Changes in transport behaviour during the Covid-19 crisis. [https://www.iea.org/articles/changes-in-transport-behaviour-during-the-covid-19-crisis], accessed on 28/09/2021.

27 Eisenmann, C., Nobis, C., Kolarova, V., Lenz, B., Winkler, C.: Transport mode use during the COVID-19 lockdown period in Germany: The car became more important, public transport lost ground, Transport policy, 103(March 2021), [https://doi.org/10.1016/j.tranpol. 2021.01.012], pp. 60-67. 
It is definitely a good sign that in some EU member states (Switzerland, France, and Germany) passenger transit in public transport has come close to the pre-pandemic numbers, but there are still countries where people are slow to regain the trust in public transportation. ${ }^{28}$ The Netherlands is recording a considerable drop in the number of passengers in public transport. Before the pandemic, around 938,000 passengers used the public transport services daily and this number dropped to $300,000 .^{29}$ It should be taken into consideration that the pandemic has caused changes in transport behavior and, for some countries, it will take time to catch up with the numbers from before the pandemic. Besides the fact that changes have happened in the transport behavior, there are still many who work from home and this too influences the slow reaching of the numbers from before. ${ }^{30}$ If operators want to maintain and develop their transportation systems, it is crucial that they show the passengers that public transport is safe and that they can go back to using them without risking their health. ${ }^{31}$

\subsection{MEASURES FOR PREVENTING THE SPREADING OF THE VIRUS IN PUBLIC TRANSPORT}

The transport sector has not only been impacted by the pandemic, but also by the measures certain governments have been introducing. These measures have influenced the segment of public transit in particular. ${ }^{32}$ The situation connected with the pandemic and the national measures such as lockdowns and social distancing restrictions has had a stronger impact on the travel behavior of individuals than regulations imposed by public transport providers. ${ }^{33}$

28 Luman, R.: European public transport shows signs of sustained recovery, ING Think, 01.09.2021. [https://think.ing.com/articles/european-public-transport-shows-signs-of-sustained-recovery], accessed on 15/09/2021.

29 Séveno, V. Number of people using Amsterdam public transport drops by more than half, IAM EXPAT, 13.07.2020. [https://www.iamexpat.nl/expat-info/dutch-expat-news/number-people-using-amsterdam-public-transport-drops-more-half], accessed on 15/09/2021.

30 Luman, R.: European public transport shows signs of sustained recovery, ING Think, 01.09.2021. [https://think.ing.com/articles/european-public-transport-shows-signs-of-sustained-recovery], accessed on 15/09/2021.

31 [https://www.oliverwyman.com/our-expertise/insights/2020/jul/safer-public-transportduring-covid-19.html], accessed on 12/09/2021.

32 Orro, A., Novales, M., Monteagudo, Á., Pérez-López, J. B., Bugarín, M. R.: Impact on city bus transit services of the COVID-19 lockdown and return to the new normal: the case of A Coruña (Spain), Sustainability, 12(17)2020, [https://doi.org/10.3390/su12177206], p. 7206.

33 Rasca, S., Markvica, K., Ivanschitz, B. P.: Impacts of COVID-19 and pandemic control measures on public transport ridership in European urban areas-The cases of Vienna, Inns- 
Many serious measures have been implemented by the public transport authorities and operators since the outbreak of the pandemic ${ }^{34}$ :

- Adapting the transport supply;

- Improving cleaning and disinfection procedures;

- Supplying protective equipment to their staff and passengers;

- Ensuring staff and passengers comply with health regulations;

- Increasing the level of natural ventilation and air renewal;

- Accelerating the digitalization and the deployment of IT tools to better monitor their operations;

- Anticipating the number of travelers and occupancy in vehicles to provide real-time information to avoid crowds;

- Arranging contactless payment facilities; and

- Providing their staff and customers with regular transparent communications.

Strategies that are suggested through international and national are following: ${ }^{35}$

1. keep the public informed,

2. stay at home when sick, and

3. minimize public transport use.

The main issue with organizing public transport in pandemic times is the reduction of the capacity. Practices that have been proven successful for overcoming this challenge $\operatorname{are}^{36}$ :

\section{Increase transport capacity}

2. Limit occupancy to enable physical distancing

bruck, Oslo, and Agder, Transportation Research Interdisciplinary Perspectives, Vol.10(June)2021, [https://doi.org/10.1016/j.trip.2021.100376], p. 100376.

34 The International Association of Public Transport (UITP): Public transport is COVID safe. Brussels: UITP, October 2020. [https://cms.uitp.org/wp/wp-content/uploads/2020/10/ Policy-Brief-PTisCOVID-Safe.pdf], accessed on 05/09/2021

35 Zhen, J., Chan, C., Schoonees, A., Apatu, E., Thabane, L., Young, T.: Transmission of respiratory viruses when using public ground transport: A rapid review to inform public health recommendations during the COVID-19 pandemic, South African Medical Journal, 110(June 2020), [https://doi.org/ 10.7196/SAMJ.2020.v110i6.14751], pp. 478-483.

36 Krell, K., Hunkin, S.: Making Public Transport safe \& acceptable in times of cOVID-19. Interreg Europe. Policy Learning Platform, 07 July 2020. [https://www.interregeurope.eu/fileadmin/user_upload/plp_uploads/PLP_COVID-PublicTransport.pdf], accessed on 12/09/2021. 
3. Shift travel demand away from peak hours

4. Help passengers make choices that alleviate crowding

5. Enact safety measures for public transport users

6. Restore confidence through communication and public relations measures.

In situations when usage is unavoidable, environmental control, respiratory etiquette, and hand hygiene are recommended. The risk-based approach is needed to guide the use of non-medical masks. ${ }^{37}$ The upside is that all countries have, regardless of the extremely high costs of the battle against the coronavirus in public transport, displayed a high level of responsibility ${ }^{38}$, trying to ensure the highest level of safety for their employees and their passengers by implementing the recommended measures.

Improved ventilation can help in reducing of increased risk of viral transmission in public transportation. ${ }^{39}$ Compliance with the rules is not that difficult to achieve because a lot of people are working from home and because of other limitations, the demand for public transportation has significantly decreased and the results of the current research in the selected European cities have shown that the drop comes down to only $10-15 \%$ of the transit numbers from the pre-pandemic period. With the analysis of the methods used in some of the European cities Mckinsey has pointed out three strategies that have been used to try to deal with the challenges of passenger transit in public transport ${ }^{40}$ :

1. Limit ridership to enable physical distancing. To be able to realize this, most countries have resorted to enabling the use of public transport only for those working in the sectors of extreme importance (healthcare, law

37 Zhen, J., Chan, C., Schoonees, A., Apatu, E., Thabane, L., Young, T.: Transmission of respiratory viruses when using public ground transport: A rapid review to inform public health recommendations during the COVID-19 pandemic, South African Medical Journal, 110(June 2020), [https://doi.org/ 10.7196/SAMJ.2020.v110i6.14751], pp. 478-483.

38 The International Association of Public Transport (UITP): Public transport is COVID safe. Brussels: UITP, October 2020. [https://cms.uitp.org/wp/wp-content/uploads/2020/10/ Policy-Brief-PTisCOVID-Safe.pdf], accessed on 05/09/2021.

39 Zhen, J., Chan, C., Schoonees, A., Apatu, E., Thabane, L., Young, T.: Transmission of respiratory viruses when using public ground transport: A rapid review to inform public health recommendations during the COVID-19 pandemic, South African Medical Journal, 110(June 2020), [https://doi.org/ 10.7196/SAMJ.2020.v110i6.14751], pp. 478-483.

40 Chapuis, R., Tadjeddine, K., Chinn, D., Holmes, R., Knol, A., Speksnijder, L., Wolfs, K., Lotz, C., Stern S.: Restoring public transit amid COVID-19: What European cities can learn from one another, 05.06.2020. [https://www.mckinsey.com/industries/travel-logistics-and-infrastructure/our-insights/restoring-public-transit-amid-covid-19-what-european-cities-canlearn-from-one-another, accessed on 19/09/2021. 
enforcement, and the food supply chain) while the rest (students, office workers, etc.) have been encouraged to stay at home. To prevent crowding, governments may want to consider continuing to advise against all nonessential trips.

2. Stagger ridership throughout the day and across the transit system. Physical distancing is enabled by shifting demand away from peak hours. Additionally, it also makes the rides more pleasant. There is a possibility for schools and universities to spread start times over the day (like in the example of the Netherlands). There is also the possibility of limiting the service.

3. Institute rules and changes that safely increase system capacity. There have to be precautionary health measures introduced that will be strictly followed by the passengers if the operators want to increase the capacity of public transit. In most countries, it is mandatory for passengers to wear a mask in public transport and almost everywhere, it is obligatory to put up a barrier between the driver and the passengers' area.

There are some additional measures for increasing the capacities of public transit. Mass transit operators can encourage employers to rearrange the schedules, so the ridership could be spread out over the day or week. There are many advantages to this coordination, one of them being the possibility to invest in maintenance, upgrades, and modernization ${ }^{41}$ instead to expand and add additional capacities. Trust in the safety of public transport needs to be earned again and this is particularly true for the developing countries. Of course, safety measures need to be maintained and strictly controlled. ${ }^{42}$ Countries will need to develop clever policies to determine whether these changes in mobility caused by COVID-19 are positive or negative, while their impacts on energy use, safety, and long-term environmental and health outcomes are observed. ${ }^{43}$ Operators around the world have implemented many of these measures in different ways, but all of them have the same goal: to reduce the risk from virus transmission in public transport and to enable the users to feel safe while using public transport services. It is crucial to regain the trust of the passengers as soon as possible because some of them think even the precautions taken cannot prevent the spreading of the infection.

\footnotetext{
${ }^{41}$ [https://www.oliverwyman.com/our-expertise/insights/2020/jul/safer-public-transportduring-covid-19.html], accessed on 12/09/2021.

42 Abdullah, M., Ali, N., Dias, C., Campisi, T., Javid, M. A.: Exploring the Traveler's Intentions to Use Public Transport during the COVID-19 Pandemic While Complying with Precautionary Measures, Applied Sciences, 11(8)2021, [https://doi.org/10.3390/app11083630], p. 3630.

43 Sung, J., Monschauer, Y.: Changes in transport behaviour during the Covid-19 crisis. [https://www.iea.org/articles/changes-in-transport-behaviour-during-the-covid-19-crisis], accessed on 28/09/2021.
} 


\section{CHARACTERISTICS OF PUBLIC TRANSPORT IN THE CITY OF ZAGREB DURING THE PANDEMIC}

This section of the paper analyses the measures introduced by the Civil Protection Headquarters in the Republic of Croatia which have regulated the public transport sector and aimed at the prevention of the transmission of coronavirus infection. The second subsection addresses the mobility in passenger transit by buses, trams, and the funicular in the City of Zagreb.

\subsection{HEALTH MEASURES IN PUBLIC TRANSPORT DURING THE CORONAVIRUS PANDEMIC IN CROATIA}

When the first case of the COVID-19 disease was confirmed in Croatia, in February 2020, more rigorous measures for the mobility of the population have been introduced. They were implemented in the enclosed areas and facilities such as shopping centers, local shops, and public transit vehicles. The Civil Protection Headquarters in Croatia issued the Decision on temporary ban of public transport which took effect on 21 March 2020. The decision affected the following public transport services ${ }^{44}$ :

- scheduled public passenger transit in the national road transport, except for the taxi service

- scheduled public passenger transit in the international road service

- public railroad passenger service

- tram and other urban public transit and

- all other modes of transport not mentioned above (cable cars, funiculars, etc.).

Together with the above-mentioned Decision, on the same day, the Headquarters issued the Decision on the measures for limiting public transit in regular coastal maritime transit ${ }^{45}$, which limited public transportation of the passengers, freight, and vehicles to and from the islands and the Pelješac peninsula in the Republic of Croatia. This Decision was suspended on 18 May $2020^{46}$, while

\footnotetext{
${ }_{44}$ [https://civilna-zastita.gov.hr/UserDocsImages/CIVILNA\%20ZA\%C5\%A0TITA/PDF_ ZA\%20WEB/Odluka\%20o\%20zabrani\%20javnog\%20prometa.pdf], accessed on 21/09/2021.

45 [https://civilna-zastita.gov.hr/UserDocsImages/CIVILNA\%20ZA\%C5\%A0TITA/PDF_ ZA\%20WEB/Odluka\%20o\%20zabrani\%20javnog\%20prometa.pdf], accessed on 21/09/2021.

46 Narodne novine: Odluka o mjerama ograničavanja javnog prijevoza u linijskom obalnom pomorskom prometu, broj 34(2020) [https://narodne-novine.nn.hr/clanci/sluzbeni/2020_03_ 34_732.html], accessed on 21/09/2021.
} 
regular public passenger transit in national and international road transport and public international and intercity passenger railroad transit normalized in June 2020. Some other EU member states opted for the temporary discontinuation of public transport and this very decision brought on a huge challenge for the decision-makers. The challenge was how to enable the mobility of those who needed to commute. All the decision-makers in almost all the countries agreed that with the reinstatement of public transport, the number of passengers should be reduced to $15-35 \%$ in relation to the pre-pandemic period. ${ }^{47}$

The measures introduced then are still in effect now and they mandate that the drivers, as well as all the other employees working on the transport vehicles, and the passengers, are compelled to wear medical or face masks in a proper way during the rides. They also must follow the general anti-pandemic measures and special recommendations issued by the Croatian Institute for Public Health in cooperation with the Department for Public Health that pertain to using the public transport services. ${ }^{48}$ The Directorate of the Civil Protection Headquarters, together with the Department for Public Health has been monitoring the situation carefully and revising or suspending these decisions accordingly.

The European Investment Bank has carried out a survey about the health concerns related to public transport, and it confirms that people worldwide are equally concerned for their health in public transport: $75 \%$ of the Americans, $71 \%$ of the Chinese, and $67 \%$ of the Europeans express high concerns and are less likely to use public transport due to the risk of COVID-19 infection. ${ }^{49}$

${ }^{47}$ Chapuis, R., Tadjeddine, K., Chinn, D., Holmes, R., Knol, A., Speksnijder, L., Wolfs, K., Lotz, C., Stern S.: Restoring public transit amid COVID-19: What European cities can learn from one another, 05.06.2020. [https://www.mckinsey.com/industries/travel-logistics-and-infrastructure/our-insights/restoring-public-transit-amid-covid-19-what-european-cities-canlearn-from-one-another], accessed on 19/09/2021.

48 [https://www.koronavirus.hr/organizacija-javnog-prijevoza/869], accessed on 21/09/2021.

49 [https://www.eib.org/en/infographics/67-percent-eu-avoiding-public-transport-health-concerns], accessed on 18/09/2021. 
Picture 1. Percentage of respondents with a negative attitude towards public transport per member states

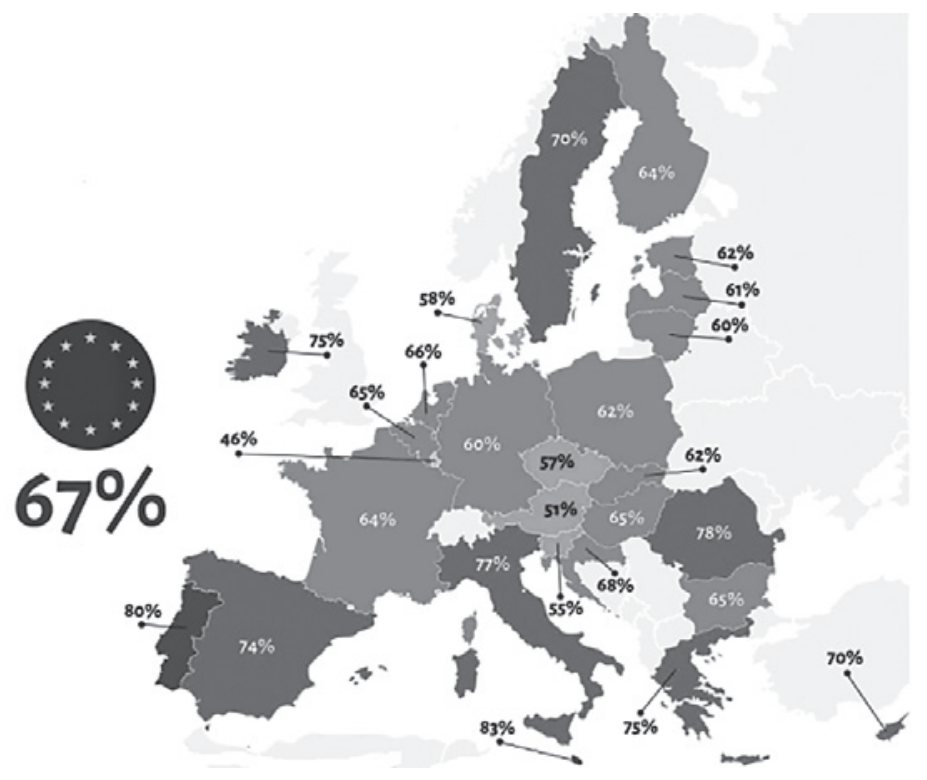

Source: [https://www.eib.org/en/infographics/67-percent-eu-avoiding-public-transport-healthconcerns], accessed on 18/09/2021

Picture 1 shows how the percentage is particularly high in Italy (77\%), Romania $(78 \%)$, Portugal $(80 \%)$, and Malta $(83 \%)$, while Croatia is only $1 \%$ above the average value for the European Union i.e., $68 \%$ of the respondents said they would not use public transport services because they were afraid for their health. Bearing in mind that Italy is the country in Europe that has been maybe the most harshly stricken by the disease and there have been many deceased, it is no wonder that the number of people who are afraid of using public transport is almost the highest in the EU.

Recommendations for operating bus transport can be sorted into two groups. The first group of recommendations are the measures the drivers need to follow, and they are ${ }^{50}$.

1. Maintain hygiene in the driver's cabin and keep the workspace clean.

2. If wearing the mask does not obstruct safety, the driver should wear a mask during the driving and change it regularly.

50 [https://www.koronavirus.hr/organizacija-javnog-prijevoza/869], accessed on 21/09/2021. 
3. It is necessary to regularly sanitize the hands.

4. Avoid touching the eyes, mouth, and nose with your hands.

5. Minimize close contact with the passengers and their luggage.

6. Instruct the passengers to keep the distance of at least one meter.

7. Inform the passengers on how the coronavirus is transmitted: by contact and through respiratory droplets.

8. Cover the nose with the inner side of the elbow or a paper handkerchief when coughing or sneezing.

9. Clean and ventilate the vehicle (the bus) before and after the ride.

10. Put up a physical barrier between the driver's area and the passengers (e.g., a plexiglass barrier). If this is not possible, the first row of seats behind the driver cannot be used for passenger transport.

11. The number and the seating arrangement of the passengers should comply with the recommended distance between the passengers.

12. It is necessary to regularly ventilate the passenger area at the bus stops. Also, during the rides, it is necessary to use the ventilation inside the vehicle. If the weather and the temperature allow, the windows should be kept open.

13. At ticket offices, passengers should be encouraged to use contactless modes of payment or online payment options, and if the usual card payment or cash are used, the hands should be disinfected afterward.

14. If the employees or the members of their families develop the symptoms to suggest the COVID-19 disease (elevated body temperature, sore throat, coughing, respiratory problems) they should stay at home and inform the employer at once.

The second group of the measures are those the passengers need to follow, first and foremost, hand disinfection upon boarding, wearing a face mask, and keeping the safety distance.

Unfortunately, so far, the demand for public transport has been reduced. The reasons for that are the lockdowns, but also the fear of catching the virus when using public transport services people have been experiencing. ${ }^{51}$ The proof that the precautionary measures have had a positive effect on the passengers' attitude towards public transport in the Republic of Croatia is evident in the num-

51 Sung, J., Monschauer, Y.: Changes in transport behaviour during the Covid-19 crisis. [https://www.iea.org/articles/changes-in-transport-behaviour-during-the-covid-19-crisis], accessed on 28/09/2021. 
bers that have been recorded. In 2020, public buses carried a total of 125,720 thousand passengers, which is $67.9 \%$ of the traffic realized in 2019. Public trams carried 131,428 thousand passengers in the year $2020(65,4 \%$ of traffic from 2019). Although the drop in urban bus and tram transport is slightly higher than $30 \%$, it should be taken into consideration that this drop is considerably smaller than in most other EU member states. The average drop in public transport in the European Union during the first coronavirus outbreak was 60 $80 \%$, while the drop in the second outbreak was between 40 and $60 \%$. In the first half of 2021, the number of passengers in public transport in Croatia was $55.5 \%$ higher than in the first half of $2020 .^{52}$ The recovery is not just recorded in public transport, but also in other segments of passenger transport (scheduled road transport, railroad, maritime and coastal, air transit). ${ }^{53}$ According to data from the studies in other European countries presented earlier in the paper, the conclusion can be made that the drop is not so dramatic i.e., that in Croatia, the health safety of public transport has not been brought into question by the respondents, as is the case in most European countries. No doubt, it is necessary to revise the existing public transport strategies and they should encompass European standards for prevention and detection of specific dangers, pandemics included, as well as the procedures for ensuring safe mobility for the people during crises. ${ }^{54}$

\subsection{PUBLIC TRANSPORT IN THE CITY OF ZAGREB}

In the City of Zagreb, the public transportation system encompasses the urban-suburban rail, the TAXI service, and the ZET (The Zagreb Electrical Tram) with the tram and bus subsystem and the city funicular. ${ }^{55}$ In line with the Decision issued by the Civil Protection Headquarters in Croatia, due to the increased risk from the COVID-19 disease transmission in public transport, in the Zagreb City area, the public transport by tram, bus, and funicular was completely brought to a halt from March 22 to April 26, 2020. Non-scheduled

52 [https://www.dzs.hr/Hrv_Eng/publication/2021/05-01-01_02_2021.htm], accessed on $25 / 09 / 2021$

53 Croatian Bureau of statistics: Effects of the COVID-19 pandemic on socioeconomic indicators. [https://www.dzs.hr/Eng/Covid-19/transport.html], accessed on 25/09/2021.

54 Struzik, A.: Javni prijevoz nakon COVID-a - potreba za inovativnim i sigurnim rješenjima za trenutačnu i moguće buduće krize, 08.12.2020. [https://cor.europa.eu/hr/news/Pages/transport-publiczny-po-covidzie.aspx], accessed on 28/09/2021.

55 [https://www.zgportal.com/zgservis/sustav-javnog-prijevoza-u-gradu-zagrebu/], accessed on $26 / 09 / 2021$. 
bus transport was organized for those employed in public and other services under the Civil Protection Headquarters' authority in the City of Zagreb. ${ }^{56}$

\section{Chart 1. Urban transport according to the types of public transport in the City of Zagreb, 2016-2020 (000)}

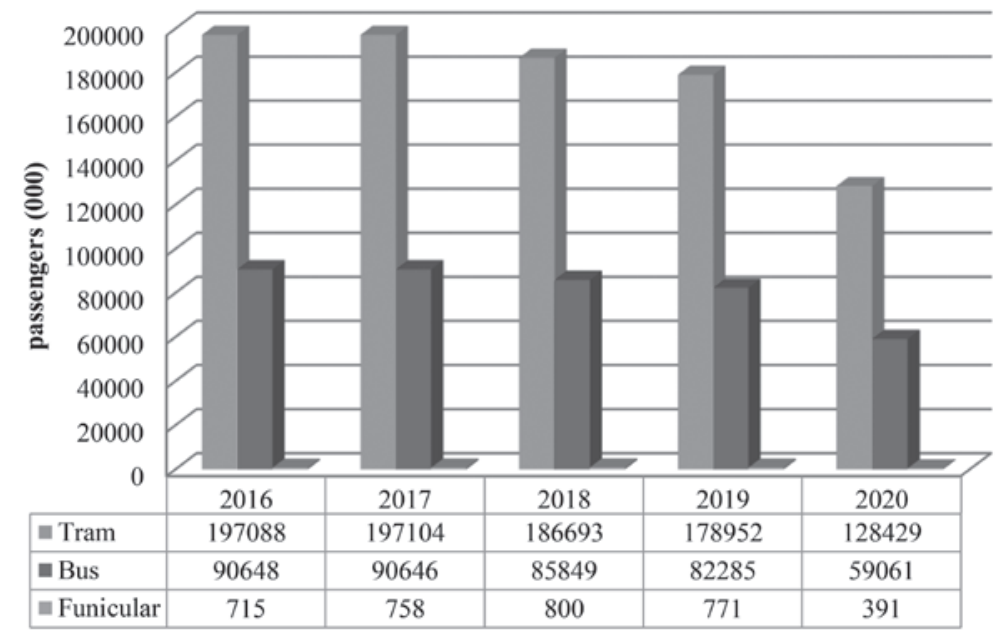

Source: author compiled according to data from https://zagreb.hr/prijevoz/1032

Chart 1 shows public transport in the City of Zagreb by the type of transport: buses, trams, and the funicular for the period from 2016 to 2020. Obviously, the buses carried most of the passengers, $70 \%$. In 2020, urban tram and bus transit record a drop of around 29\% (see Table 1). Those figures, although they seem high, represent a good trend because the situation in other European cities was much worse, with the figures going between $40 \%$ and $60 \% 57$. For example, in six big cities in Spain, public transport suffered more than a $50 \%$ drop. $^{58}$

\footnotetext{
56 [https://koronavirus.hr/zupanije/grad-zagreb/javni-prijevoz/205], accessed on 26/09/2021.

57 Bernhardt, J.: Decline in ridership, adapted timetables and disinfection-robots - The impact of Corona/Covid-10 on public transport, Urban Transport Magazine, 25.03.2020. [https:// www.urban-transport-magazine.com/en/decline-in-ridership-adapted-timetables-and-disinfection-robots-the-impact-of-corona-covid-10-on-public-transport/], accessed on 05/09/2021.

58 Medina, M.A., Grasso, D.: Less travel, fear of contagion: Why Spain's public transportation is facing its biggest crisis ever, 18.01.2021. [https://english.elpais.com/spanish_news/202101-18/less-travel-fear-of-contagion-why-spains-public-transportation-is-facing-its-biggest-crisis-ever.html], accessed on 26/09/2021.
} 
Table 1. Public transport in the City of Zagreb by the type of transport in 2019 and 2020

\begin{tabular}{|l|c|c|c|}
\hline & $\mathbf{2 0 1 9}$ & $\mathbf{2 0 2 0}$ & $\begin{array}{c}\text { INDEX } \\
\mathbf{2 0 2 0} / \mathbf{2 0 1 9}\end{array}$ \\
\hline Tram & 178952 & 128429 & 71.77 \\
\hline Bus & 82285 & 59061 & 71.78 \\
\hline Funicular & 771 & 391 & 50.71 \\
\hline TOTAL & $\mathbf{2 6 2 0 0 8}$ & $\mathbf{1 8 7 8 8 1}$ & $\mathbf{7 1 . 7 1}$ \\
\hline
\end{tabular}

Source: The Republic of Croatia, City of Zagreb, City Office for the Strategic Planning and Development of the City. Department for Statistical and Analytical Affairs: Announcement TRANSPORT, January - December 2020, 2 March 2021

It is evident that the biggest drop during the coronavirus pandemic has been recorded for the funicular. The number of passengers that used the funicular dropped by half. This type of transport has suffered a drop of more than 20 percentage points in relation to the recorded drop in urban tram and bus transit. The reason for this may lie in the fact that the funicular operates only at one point in the city and the capacity could not be increased. On the other hand, one should not ignore the fact that in 2020 , the City of Zagreb was visited by almost $75 \%$ fewer tourists than in $2019^{59}$, and the tourists are mostly those who use the funicular in the first place due to its attractiveness as a famous landmark. The funicular records the biggest drop in the first half of 2021 when 159,801 passengers used the service, i.e., $23.11 \%$ fewer than in the first half of $2020 .{ }^{60}$ This number is considerably smaller than in the year before, which implies that this type of transit has started to recover, but the process is slower because tourism is on the mending path, too. The Zagreb funicular is also the oldest public service for passenger transit in Zagreb and it is protected as the city's cultural heritage ${ }^{61}$, which is one more reason for being attractive to tourists.

\footnotetext{
59 [https://www.zagreb.hr/turisticki-pokazatelji-i-smjestajni-kapaciteti/1031], accessed on $26 / 09 / 2021$

60 Republika Hrvatska Grad Zagreb. Gradski ured za strategijsko planiranje i razvoj grada. Odjel za statističke i analitičke poslove: PRIJEVOZ siječanj-lipanj 2021. [https://zagreb.hr/ prijevoz/1032], accessed on 28/09/2021

${ }_{61}$ [https://www.infozagreb.hr/planiranje-putovanja/kretanje-po-gradu/javni-prijevoz-i-parking/uspinjaca-54a11ce6158a7], accessed on 26/09/2021
} 
Chart 2. Tram and bus transit in the City of Zagreb, the first half of 2020 and $2021(000)$

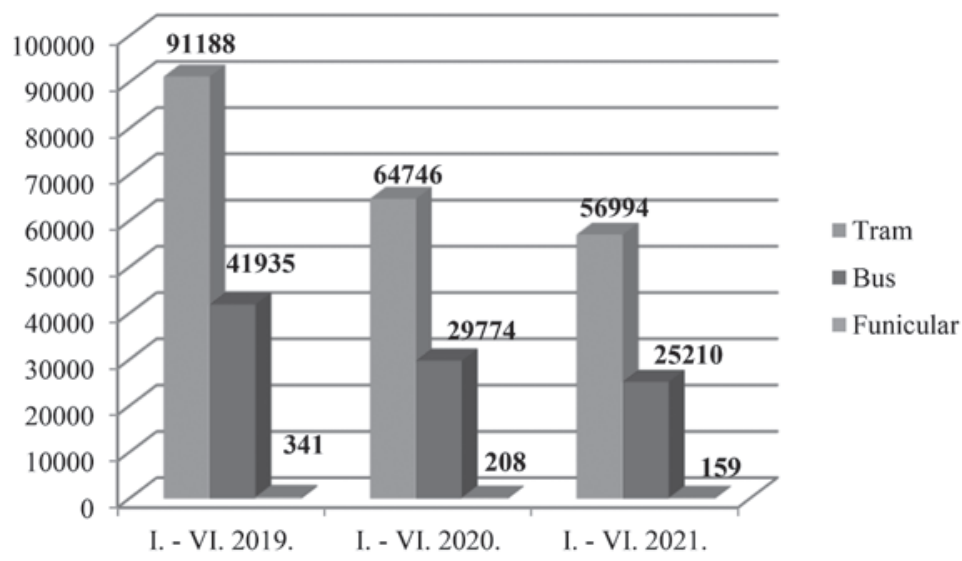

Source: author compiled according to data from The Republic of Croatia, City of Zagreb, City Office for the Strategic Planning and Development of the City. Department for Statistical and Analytical Affairs: Announcement TRANSPORT, January - June 2020 - 2021 [https://zagreb. hr/prijevoz/1032], accessed on 28/09/2021

Public transport in the City of Zagreb has been recording very good results in the first half of 2021. Compared to the year 2020, the drop in urban tram transit for the first half of 2021 was $12 \%$, and $15.33 \%$ for bus transit. Although these rates are on the negative side, it should be noted that they are considerably smaller than in the year before recorded in some European cities. The best path towards recovery for the City of Zagreb would be promoting the public transit services as being safe and making sure that the passengers know how public transport providers are doing all they can to bring the risk down to the minimum. Bringing tourists back is also crucial for the recovery of public transit in the City.

\section{CONCLUSION}

In the past, we faced several pandemics, but none has influenced all the segments of life and the entire society such as the coronavirus pandemic. Unlike those before, this pandemic has considerably affected the mobility of the population. Global air transport has almost been left paralyzed, except for air freight transport and the situation has not been much different on the ground. The first outbreak brought the biggest drop in passenger transit and the following drops, though being high, still have been smaller than that first shocking 
one. The drop in passenger transit in public transport is partly the consequence of the limitations introduced in public transport, partly the result of many people staying and working from home, and partly caused by the fear that public transport is not safe.

Almost all EU member states have been forced to implement measures for reducing the risk of COVID-19 transmission in public transport. The big issues in the further implementation of these measures are the costs and the questionable functioning of the system in those conditions. It is vital that the public is informed on the steps that are being taken to ensure safety and minimize the health risks, therein regaining the passengers' trust in the public transport system. The studies have so far confirmed that a certain number of users have no intention of using these services in the future for fear of their health and that is why more people cycle or use their private vehicles for commuting. The increased use of private vehicles is definitely not in anybody's best interest since the efforts made by the EU over the last decade, in particular, have been aimed at reducing pollution and the carbon footprint.

In the Republic of Croatia, as well as in other countries, public transit was temporarily completely closed, and ever since has been limited by safety measures. The analysis of the transit in the Republic of Croatia and its capital shows the drop-off passengers in all transportation types in public transit, but this drop is smaller than in most other EU member states. With the aim of returning to the state from before the pandemic as soon as possible, it is necessary to revise the existing strategies in public transport. They should encompass European standards for the prevention and detection of specific dangers and the procedures for ensuring safe mobility for people during crises. Since Croatia is oriented towards tourism, it is crucial to regain the trust of the tourist as well, because otherwise, regardless of the revision of the strategies, it will be hard to reach the numbers from before the pandemic.

\section{LITERATURE}

1. Abdullah, M., Ali, N., Dias, C., Campisi, T., Javid, M. A.: Exploring the Traveler's Intentions to Use Public Transport during the COVID-19 Pandemic While Complying with Precautionary Measures, Applied Sciences, 11(8)2021.

- DOI: https://doi.org/10.3390/app11083630

2. Bernhardt, J.: Decline in ridership, adapted timetables and disinfection-robots The impact of Corona/Covid-10 on public transport, Urban Transport Magazine, 25.03.2020. [https://www.urban-transport-magazine.com/en/decline-in-ridershipadapted-timetables-and-disinfection-robots-the-impact-of-corona-covid-10-onpublic-transport/], accessed on 05/09/2021. 
3. Borkowski, P., Jażdżewska-Gutta, M., Szmelter-Jarosz, A.: Lockdowned: Everyday mobility changes in response to COVID-19, Journal of Transport Geography, 90(January 2021).

- DOI: https://doi.org/10.1016/j.jtrangeo.2020.102906

4. Budd, L., Ison, S.: Responsible Transport: A post-COVID agenda for transport policy and practice, Transportation Research Interdisciplinary Perspectives, 6(July 2021).

- DOI: https://doi.org/10.1016/j.trip.2020.100151

5. Chapuis, R., Tadjeddine, K., Chinn, D., Holmes, R., Knol, A., Speksnijder, L., Wolfs, K., Lotz, C., Stern S.: Restoring public transit amid COVID-19: What European cities can learn from one another, 05.06.2020. [https://www.mckinsey. com/industries/travel-logistics-and-infrastructure/our-insights/restoring-publictransit-amid-covid-19-what-european-cities-can-learn-from-one-another, accessed on $19 / 09 / 2021$.

6. Croatian Bureau of statistics: Effects of the COVID-19 pandemic on socioeconomic indicators. [https://www.dzs.hr/Eng/Covid-19/transport.html], accessed on 25/09/2021.

7. Croatian Bureau of Statistics: Transport first quarter of 2021, 14.05.2021. [https:// www.dzs.hr/Hrv_Eng/publication/2021/05-01-01_01_2021.htm], accessed on 25/09/2021.

8. Culbertson, A., Aguilar-Garcia, C.: Coronavirus: Why public transport could be safer than we thought, Sky News, 07.10.2021. [https://news.sky.com/story/coronavirus-why-public-transport-could-be-safer-than-we-thought-12091657], accessed on $11 / 10 / 2021$.

9. Eisenmann, C., Nobis, C., Kolarova, V., Lenz, B., Winkler, C.: Transport mode use during the COVID-19 lockdown period in Germany: The car became more important, public transport lost ground, Transport policy, 103(March 2021).

- DOI: https://doi.org/10.1016/j.tranpol.2021.01.012

10. European Commission: Clean transport, Urban transport, Public transport. [https://ec.europa.eu/transport/themes/urban/urban_mobility/urban_mobility_ actions/public_transport_en], accessed on 11/09/2021.

11. Krell, K., Hunkin, S.: Making Public Transport safe \& acceptable in times of cOVID-19. Interreg Europe. Policy Learning Platform, 07 July 2020. [https:// www.interregeurope.eu/fileadmin/user_upload/plp_uploads/PLP_COVID-PublicTransport.pdf], accessed on 12/09/2021.

12. Lock, O.: Cycling Behaviour Changes as a Result of COVID-19: A Survey of Users in Sydney, Australia, Findings, 2020.

- DOI: https://doi.org/10.32866/001c.13405

13. Luman, R.: European public transport shows signs of sustained recovery, ING Think, 01.09.2021. [https://think.ing.com/articles/european-public-transport-shows-signs-of-sustained-recovery], accessed on 15/09/2021. 
14. Medina, M.A., Grasso, D.: Less travel, fear of contagion: Why Spain's public transportation is facing its biggest crisis ever, 18.01.2021. [https://english.elpais. com/spanish_news/2021-01-18/less-travel-fear-of-contagion-why-spains-publictransportation-is-facing-its-biggest-crisis-ever.html], accessed on 26/09/2021.

15. Morita, H.; Nakamura, S.; Hayashi, Y.: Changes of Urban Activities and Behaviors Due to COVID-19 in Japan, SSRN Electron, May 2020. [https://papers.ssrn. com/sol3/papers.cfm?abstract_id=3594054], accessed on 14/09/2021.

- DOI: https://doi.org/10.2139/ssrn.3594054

16. Narodne novine: Odluka o mjerama ograničavanja javnog prijevoza u linijskom obalnom pomorskom prometu, broj 34(2020) [https://narodne-novine.nn.hr/clanci/sluzbeni/2020_03_34_732.html], accessed on 21/09/2021.

17. Orro, A., Novales, M., Monteagudo, Á., Pérez-López, J. B., Bugarín, M. R.: Impact on city bus transit services of the COVID-19 lockdown and return to the new normal: the case of A Coruña (Spain), Sustainability, 12(17)2020.

- DOI: https://doi.org/10.3390/su12177206

18. Przybylowski, A., Stelmak, S., Suchanek, M.: Mobility behaviour in view of the impact of the COVID-19 pandemic-public transport users in Gdansk case study, Sustainability, 13(1)2021.

- DOI: https://doi.org/10.3390/su13010364

19. Rasca, S., Markvica, K., Ivanschitz, B. P.: Impacts of COVID-19 and pandemic control measures on public transport ridership in European urban areas-The cases of Vienna, Innsbruck, Oslo, and Agder, Transportation Research Interdisciplinary Perspectives, Vol.10(June)2021.

- DOI: https://doi.org/10.1016/j.trip.2021.100376

20. Republika Hrvatska Grad Zagreb. Gradski ured za strategijsko planiranje i razvoj grada. Odjel za statističke i analitičke poslove: Priopćenje PRIJEVOZ siječanj-prosinac 2020, 02.03.2021. [https://www.zagreb.hr/userdocsimages/arhiva/statistika/2017/prijevoz\%20i\%20skladistenje\%202017/Prijevoz\%20IV\%20 tromj\%202017..pdf], accessed on 24/09/2021

21. Republika Hrvatska Grad Zagreb. Gradski ured za strategijsko planiranje i razvoj grada. Odjel za statističke i analitičke poslove: PRIJEVOZ siječanj-lipanj 2021. [https://zagreb.hr/prijevoz/1032], accessed on 28/09/2021

22. Schmöcker, J. D., Bell, M. G., Lam, W. H. (2010): Importance of public transport, Journal of Advanced Transportation, 38(1)(2010).

- DOI: https://doi.org/10.1002/atr.5670380102

23. Séveno, V. Number of people using Amsterdam public transport drops by more than half, IAM EXPAT, 13.07.2020. [https://www.iamexpat.nl/expat-info/dutchexpat-news/number-people-using-amsterdam-public-transport-drops-more-half], accessed on 15/09/2021. 
24. Struzik, A.: Javni prijevoz nakon COVID-a - potreba za inovativnim i sigurnim rješenjima za trenutačnu i moguće buduće krize, 08.12.2020. [https://cor. europa.eu/hr/news/Pages/transport-publiczny-po-covidzie.aspx], accessed on 28/09/2021.

25. Sung, J., Monschauer, Y.: Changes in transport behaviour during the Covid-19 crisis. [https://www.iea.org/articles/changes-in-transport-behaviour-during-thecovid-19-crisis], accessed on 28/09/2021.

26. The International Association of Public Transport (UITP): Public transport is COVID safe. Brussels: UITP, October 2020. [https://cms.uitp.org/wp/wp-content/ uploads/2020/10/Policy-Brief-PTisCOVID-Safe.pdf], accessed on 05/09/2021.

27. Zhen, J., Chan, C., Schoonees, A., Apatu, E., Thabane, L., Young, T.: Transmission of respiratory viruses when using public ground transport: A rapid review to inform public health recommendations during the COVID-19 pandemic, South African Medical Journal, 110(June 2020).

- DOI: https://doi.org/ 10.7196/SAMJ.2020.v110i6.14751], pp. 478-483.

\section{ONLINE SOURCES:}

1. [https://civilna-zastita.gov.hr/UserDocsImages/CIVILNA\%20ZA\%C5\%A0TITA/PDF_ZA\%20WEB/Odluka\%20o\%20zabrani\%20javnog\%20prometa.pdf], accessed on $21 / 09 / 2021$

2. [https://ec.europa.eu/info/live-work-travel-eu/coronavirus-response/transportation-during-pandemic_en], accessed on 26/08/2021

3. [https://koronavirus.hr/zupanije/grad-zagreb/javni-prijevoz/205], accessed on 26/09/2021

4. [https://www.eib.org/en/infographics/67-percent-eu-avoiding-public-transporthealth-concerns], accessed on 18/09/2021

5. [https://www.infozagreb.hr/planiranje-putovanja/kretanje-po-gradu/javni-prijevoz-i-parking/uspinjaca-54a11ce6158a7], accessed on 26/09/2021

6. [https://www.koronavirus.hr/organizacija-javnog-prijevoza/869], accessed on $21 / 09 / 2021$

7. [https:/www.oliverwyman.com/our-expertise/insights/2020/jul/safer-publictransport-during-covid-19.html], accessed on 12/09/2021

8. [https://www.zagreb.hr/turisticki-pokazatelji-i-smjestajni-kapaciteti/1031], accessed on $26 / 09 / 2021$

9. [https://www.zgportal.com/zgservis/sustav-javnog-prijevoza-u-gradu-zagrebu/], accessed on $26 / 09 / 2021$

10. [https://zagreb.hr/prijevoz/1032], accessed on 25/09/2021 